\title{
Reproduction in female Hartmann's zebra, Equus zebra hartmannae
}

\author{
Lilian M. Westlin-van Aarde, R. J. van Aarde and J. D. Skinner \\ Mammal Research Institute, University of Pretoria, Pretoria 0002, South Africa
}

\begin{abstract}
Summary. Ovaries, fetuses and plasma were collected from zebra mares shot in the Etosha National Park in Namibia between 15 and 25 August 1983. Ovarian weight was affected by reproductive status and most of the non-pregnant mares were anoestrous. The number of follicles varied between individuals and only pro-oestrous/oestrous mares had follicles larger than $20 \mathrm{~mm}$ in diameter. The largest follicle in pregnant mares was only $9 \mathrm{~mm}$ in diameter. Corpora lutea and corpora albicantia were found in non-pregnant as well as pregnant mares: 4 pregnant mares had only corpora albicantia. The presence of secondary corpora lutea could not be confirmed in any of the pregnant mares. Implantation was estimated to occur at around 73 days of gestation, and most mares $(84 \%)$ had conceived between November and April. Peripheral concentrations of plasma progesterone during pregnancy varied from 0.5 to $2.4 \mathrm{ng} / \mathrm{ml}$.
\end{abstract}

Keywords: zebra; reproduction; ovaries; seasonality; progesterone

\section{Introduction}

Hartmann's mountain zebras (Equus zebra hartmannae) are confined to Namibia and southwest Angola. They are gregarious and their social organization is based on family groups comprising a stallion with mares and their foals (Smithers, 1983). Little has been published on reproduction in this species (see Joubert $1974 \mathrm{a}, \mathrm{b}$ ) and the closely related mountain zebra, Equus zebra zebra (Penzhorn, 1985). Mares attain sexual maturity at the age of 3 years and most foals are born between November and April (Joubert, 1974a).

The Etosha National Park is situated in a semiarid environment and is exposed to erratic but seasonal rainfall, the mean annual precipitation being $<290 \mathrm{~mm}$, most falling during the hot summer months from November to April (Weather Bureau, Dept. of Environment Affairs, Pretoria, 1968-1985).

The present paper is based on material and information collected during a culling operation when zebras were shot as part of a management operation in the Etosha National Park $\left(19^{\circ} 30^{\prime} \mathrm{S}\right.$, $\left.14^{\circ} 30^{\prime} \mathrm{E}\right)$ Namibia. The paper reflects aspects of ovarian morphology, fetal growth and peripheral concentrations of progesterone of Hartmann's mountain zebras, thus adding to our present limited knowledge of reproduction in zebras.

\section{Materials and Methods}

Ovaries, fetuses and blood were collected from mares shot during culling. Fetuses $(\mathbf{N}=32)$ were weighed, measured (crown-rump) and their ages determined using the equation $\sqrt[3]{W}=a\left(t-t_{0}\right)$, where $W=$ fetal weight, a $=$ specific growth velocity, $t=$ gestation age in days, and $t_{0}=$ the calculated intercept of the age axis (Huggett \& Widdas, 1951). Specific growth velocity (a) was calculated using a birth weight of $25 \mathrm{~kg}$ (Joubert, 1974a), where $t=362$ days (Joubert, 1974b), and $t_{0}$ as $t \times 0.3$ (Huggett \& Widdas, 1951).

Ovaries (44 pairs) were weighed, sectioned and examined under a stereomicroscope (Zeiss M5). Each ovary was divided longitudinally and each half was then sectioned in $\sim 1-\mathrm{mm}$ thick slices perpendicularly to the cut surface. 
Follicles and luteal bodies were counted and their diameters measured as a mean of two perpendicular measurements. Follicles were grouped into the size-classes $1-10 \mathrm{~mm}, 11-20 \mathrm{~mm}, 21-30 \mathrm{~mm}$ and $31-40 \mathrm{~mm}$. Corpora lutea could be measured reliably up to the regressing stages. Corpora albicantia were very irregular in shape and could not be measured. They could, however, instead be classified by their colour as brick-red, dark brown and orange bodies. Pieces of luteal tissue from all luteal bodies were fixed in $40 \%$ buffered formaldehyde and routinely prepared for light microscopy, sectioned at $7 \mu \mathrm{m}$ and stained with haematoxylin and eosin.

Non-pregnant mares were assigned to 1 of 5 reproductive phases based on the standards described for Burchell's zebra (Smuts, 1976), in which the phases are related to the activity of the ovaries (as revealed by their morphology) and the behaviour of the mares.

Blood collected during the culling operation from mares $(\mathrm{N}=12)$ and fetuses $(\mathrm{N}=17)$ was centrifuged and plasma stored at $-20^{\circ} \mathrm{C}$ until assayed for progesterone by the RIA described by van Aarde (1985). Specificity of the antiserum (No. 1521) was determined by the supplier (R. P. Millar, Department of Chemical Pathology, University of Cape Town, South Africa) and cross-reactions with other steroids were: $11 \beta$-hydroxyprogesterone, $53 \cdot 2 \%$; $11 \alpha$-hydroxyprogesterone, $24.9 \%$; $5 \alpha$-pregnane-3,20-dione, $21 \cdot 7 \%$; $17 \alpha$-hydroxyprogesterone, $2 \cdot 8 \%$; pregnenolone, $1.9 \%$; 11 -deoxycorticosterone, $2 \cdot 1 \%$; 11 -deoxycortisol, $1 \cdot 6 \%$; 3a-hydroxy-5-pregnan-20-one, $0.3 \% ; 20 \alpha$-hydroxy-4pregnane-3-one, $0.4 \%$; cortisol, $<0.1 \%$. Cross-reactions of testosterone, 4-androstenedione, oestradiol-17 $\beta$ and oestrone were all $<0.001 \%$.

The sensitivity of the assay, defined as twice the standard deviation of blank values, was $<0.1 \mathrm{ng} / \mathrm{ml}$, and intraand inter-assay coefficients of variation were $4.1 \%$ and $5.3 \%$ respectively. Recovery estimates varied from 80.5 to $83.9 \%$ (mean $82 \cdot 7 \pm 1 \cdot 90 \% ; n=3)$.

Published data on daylight hours (Buys, 1978) and rainfall (Weather Bureau, Dept. of Environmental Affairs, Pretoria 1968-1985) were used to establish the relationship between reproduction and environmental conditions.

Discrepancies in sample sizes given in the results are due to not all material being available for examination.

\section{Results}

\section{The ovary}

The ovary of Hartmann's zebra is in appearance similar to that of other equids. It is deeply embedded in the mesovarium and has an ovulation fossa (see Mossman \& Duke, 1973). The numbers and sizes of follicles and luteal bodies in the mares are given in Table 1. The ovaries of mares in pro-oestrus and oestrus were morphologically similar (see Smuts, 1976) and these mares could not be distinguished from each other.

All anoestrous mares had ovulated previously and corpora albicantia varied in number from 1 to 44 per pair of ovaries, with orange corpora albicantia being more abundant than the brick-red or dark brown bodies (these were histologically similar). The number of corpora albicantia in lactating anoestrous mares (mean 12.9 , s.d. $=12.55 ; \mathrm{N}=9$ ) did not differ significantly from the number in non-lactating anoestrous mares (mean 7.3, s.d. $=3 \cdot 84 ; \mathrm{N}=16)(t=1 \cdot 3$, d.f. $=9$; NS). All non-pregnant lactating mares were in anoestrus.

All mares in pro-oestrus/oestrus $(\mathrm{N}=5)$ had, besides the small follicles, one follicle considerably larger than the others. Corpora lutea were not present and corpora albicantia were either dark brown or orange (with histology resembling those of anoestrous mares).

Follicular development in dioestrous mares $(\mathrm{N}=4)$ was similar to that of anoestrous mares (Table 1). All 4 mares were non-lactating and they all had corpora lutea. The histology of the corpora lutea revealed relatively large cells, the vast majority with pycnotic nuclei and many lipid vacuoles.

Follicular size in lactating and non-lactating pregnant mares did not exceed $10 \mathrm{~mm}$. Nonlactating pregnant mares tended to have more follicles than did lactating pregnant mares.

The corpora lutea in the pregnant and dioestrous mares were similar and comprised relatively large cells, many with pycnotic nuclei and lipid vacuoles. The diameters of these bodies were similar in lactating and non-lactating mares, and could not be related to gestational age.

Mean paired ovarian weight of non-pregnant anoestrous mares was less than for mares in prooestrus/oestrus $(t=3.26$, d.f. $=28 ; P<0.01)$, but similar to that of dioestrous or non-lactating pregnant mares (Table 1). Ovarian weight did not change with gestational age. 
Table 1. Numbers and sizes of follicles and luteal bodies in female zebra

\begin{tabular}{|c|c|c|c|c|c|}
\hline & \multicolumn{3}{|c|}{ Non-pregnant } & \multirow{2}{*}{\multicolumn{2}{|c|}{ Pregnant }} \\
\hline & \multirow[b]{2}{*}{ Anoestrous } & \multirow{2}{*}{$\begin{array}{l}\text { Pro-oestrous/ } \\
\text { oestrous }\end{array}$} & \multirow[b]{2}{*}{ Dioestrous } & & \\
\hline & & & & Non-lactating & Lactating \\
\hline No. of mares & 25 & 5 & 4 & 6 & 4 \\
\hline Wt of paired ovaries $(\mathrm{g})$ & $34 \cdot 1(15 \cdot 0-69 \cdot 0)$ & $58 \cdot 2(30 \cdot 3-84 \cdot 2)$ & $44 \cdot 5(30 \cdot 3-51 \cdot 1)$ & $45 \cdot 7(27 \cdot 1-64 \cdot 3)$ & $35 \cdot 0(31 \cdot 1-38 \cdot 3)$ \\
\hline \multicolumn{6}{|l|}{$\begin{array}{l}\text { No. of follicles/pair } \\
\text { ovaries }\end{array}$} \\
\hline $1-10 \mathrm{~mm}$ & $20 \cdot 1(1-40)$ & $16 \cdot 8(9-32)$ & $19 \cdot 0(12-33)$ & $28 \cdot 0(2-43)$ & $18 \cdot 3(10-26)$ \\
\hline $11-20 \mathrm{~mm}$ & $0.8(0-3)$ & $2 \cdot 6(0-6)$ & $0.75(0-3)$ & $0-$ & $0-$ \\
\hline $21-30 \mathrm{~mm}$ & $0-$ & $0 \cdot 8(0-1)$ & $0 \quad-$ & $0 \ldots$ & - \\
\hline $31-40 \mathrm{~mm}$ & $0-$ & $0.4(0-1)$ & - & - & - \\
\hline $\begin{array}{l}\text { Largest diameter (mm) } \\
\text { of follicle }\end{array}$ & 15 & 40 & $17 \cdot 5$ & 9 & $6 \cdot 5$ \\
\hline \multicolumn{6}{|l|}{$\begin{array}{l}\text { No. of luteal bodies/pair } \\
\text { ovaries }\end{array}$} \\
\hline $\begin{array}{l}\text { Corpora lutea } \\
\text { Corpora albicantia }\end{array}$ & 0 & 0 & 1 & $0.5(0-1)$ & $0 \cdot 75(0-1)$ \\
\hline Brick-red & $0 \cdot 1(0-1)$ & 0 & 0 & $0 \cdot 2(0-1)$ & $0.25(0-1)$ \\
\hline Dark brown & $0 \cdot 2(0-4)$ & $0 \cdot 4(0-1)$ & 0 & $0 \cdot 3(0-1)$ & $0-$ \\
\hline Orange & $9 \cdot 0(1-44)$ & $3 \cdot 0(0-11)$ & $12 \cdot 8(3-34)$ & $5 \cdot 0(3-11)$ & $5 \cdot 0(2-7)$ \\
\hline $\begin{array}{l}\text { Largest diameter }(\mathrm{mm}) \\
\text { of luteal body }\end{array}$ & 9 & 5 & 21 & $16 \cdot 5$ & $18 \cdot 0$ \\
\hline
\end{tabular}

Values are mean and range in parentheses.

\section{Fetal growth and seasonality}

Growth in weight of fetuses is illustrated in Fig. 1 . The calculated $t_{0}$-value suggests that implantation occurred around 73 days post coitum. Data for fetal growth (crown-rump length) are presented in Fig. 2, illustrating a length of $\sim 100 \mathrm{~cm}$ at birth. The sex ratio of fetuses $(1: 1 \cdot 14)$ did not differ from unity.

Based on extrapolation from fetal ages it appeared that most ( $81 \%, \mathrm{~N}=32$ fetuses) matings occurred between November and April with a definite peak in December, this coinciding with the peak in daylight length at the beginning of the rainy season (Fig. 3).

\section{Peripheral progesterone concentrations}

Plasma progesterone concentrations in all non-pregnant mares were below $0.6 \mathrm{ng} / \mathrm{ml}$. Gestational age of mares available for this study varied from 95 to 345 days and progesterone values in these mares varied from 0.5 to $2.4 \mathrm{ng} / \mathrm{ml}$, the highest value being recorded on Day 95 of pregnancy. Progesterone concentrations in fetal plasma varied from 0.09 to $0.68 \mathrm{ng} / \mathrm{ml}$.

\section{Discussion}

Since the analysed material was collected from animals culled during August and thus 8 months after the mating peak most zebras were, as expected, in anoestrus or in the third and fourth quarter of pregnancy.

The different colours of corpora albicantia may reflect their age, as is described for the cow (Hammond, 1927) and for the horse (Arthur, 1958). The histology was, however, similar regardless of colour, and the differences may instead be ascribed to the gradual disappearance of haemosiderin from the red blood cells. 


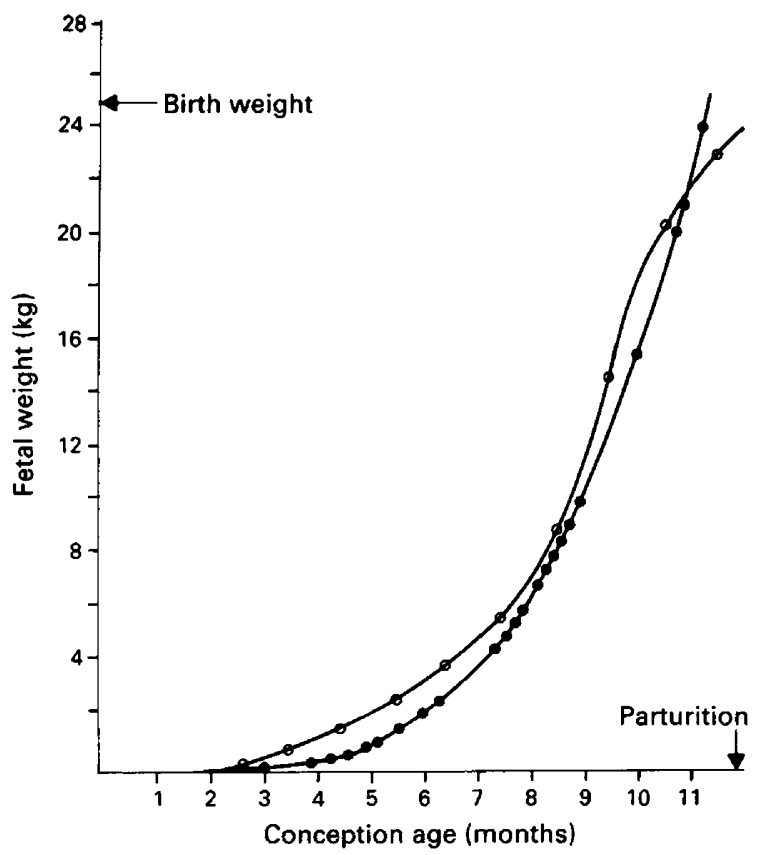

Fig. 1. Fetal growth curve (mass) for Hartmann's zebra. $\bigcirc$, according to Joubert (1974a), who used the method of Richter \& Gotze $(1950)(\mathrm{N}=5)$ and - the present study, using the equation of Huggett \& Widdas (1951) $(\mathrm{N}=32)$.

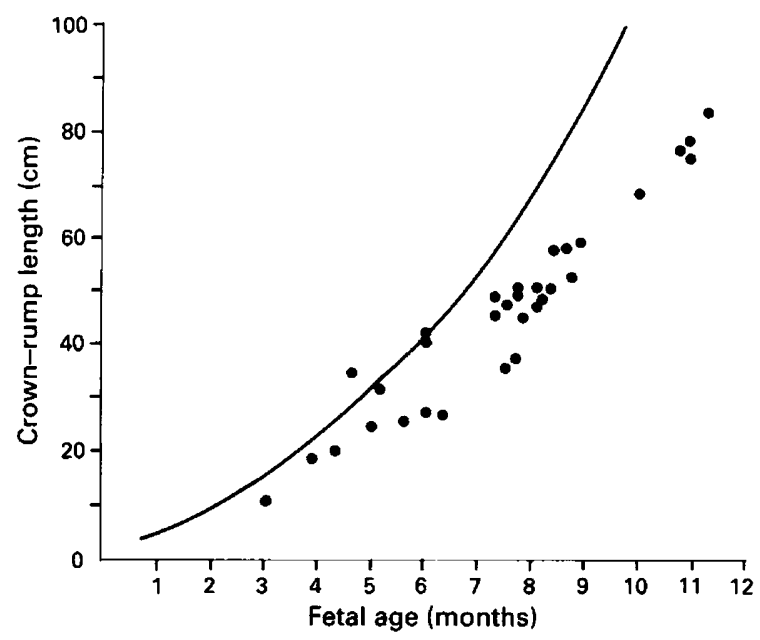

Fig. 2. Fetal growth rate (crown-rump length) in Hartmann's zebra. The solid line according to Joubert (1974a) $(\mathrm{N}=5)$ and the plot according to the present study $(\mathrm{N}=32)$. 


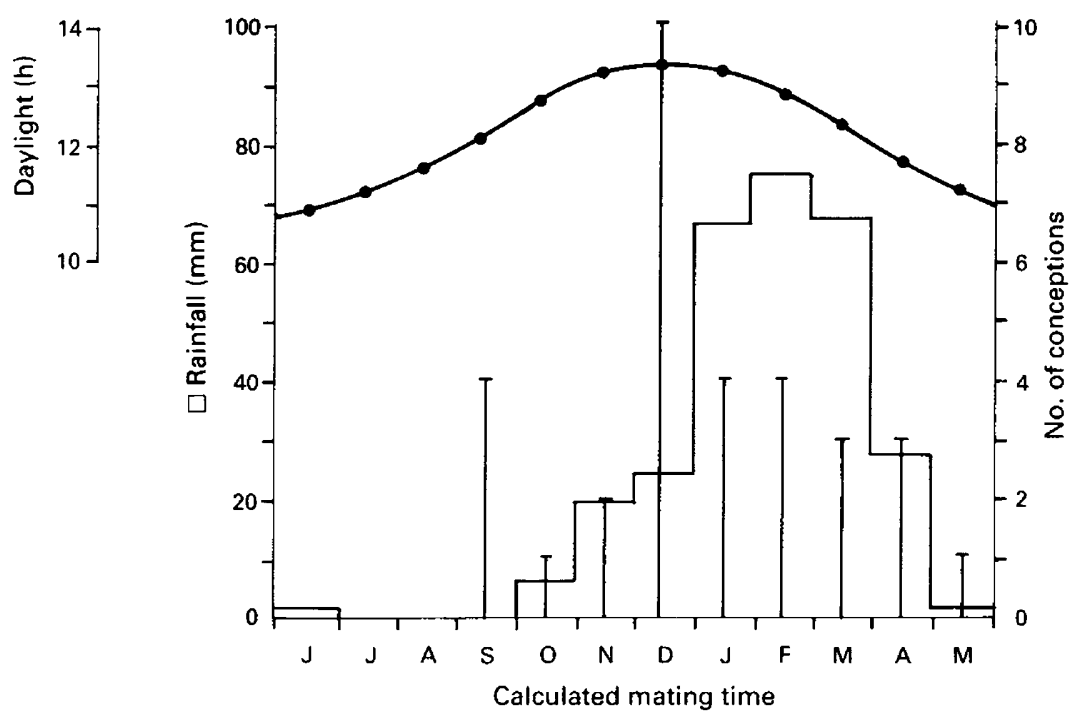

Fig. 3. Calculated mating time for pregnant Hartmann's zebra mares $(\mathrm{N}=32)$. Most matings $(81 \%)$ occurred between November and April. Daylight hours and rainfall are given as monthly mean values for the sampling area.

Several reasons for lactating mares having more luteal bodies than non-lactating mares could be suggested. Lactating mares may have been older. Furthermore, secondary corpora lutea, found after ovulation during pregnancy have been reported for Burchell's zebra (Smuts, 1976). However, Smuts (1976) found such secondary corpora lutea only in mares 70-110 days pregnant and all lactating mares in the present study were beyond that gestational age. The possibility of accessory corpora lutea, i.e. unovulated luteinized follicles, as well as thecal-type luteal tissue, should also be considered as a reason for the larger number of luteal bodies in the lactating mares.

The life-time of luteal bodies in equids has been discussed by several authors. King (1965) found in Grevy's zebra that luteal tissue from a cycle lasts only for some weeks. The large number of corpora albicantia in some females (up to 44) may either be ascribed to multiple ovulations (relatively common in the horse; Ginther (1979)), or to an extended life-time of luteal tissue (at least 6 years if the average mare experiences around 7 cycles per year). Kupfer (1928) observed that corpora lutea remained large up to 5 months of gestation in South African equines. King (1965) found the same in Burchell's zebra, and so did Joubert (1974b) in Hartmann's zebra. Other studies (see Mossman \& Duke, 1973) on Burchell's zebra suggested that the corpus luteum would last at least to term. The lowest gestation age in the pregnant mares (from which ovaries were sampled) of the present study was 182 days.

Amongst the non-pregnant mares, lactating females were only found in the anoestrous group. This suggests that if the mare does not conceive during post-partum oestrus she will be in anoestrus until the next season.

At all stages, the ovaries of Hartmann's zebras were heavier than those reported by Smuts (1976) for Burchell's zebra (e.g. 34.6 and $9.9 \mathrm{~g}$ for anoestrous mares; 58.2 and $25.1 \mathrm{~g}$ for prooestrous/oestrous mares and 48.4 and $18.0 \mathrm{~g}$ for dioestrous mares).

It has been reported (Smuts, 1976) that the ovaries of Burchell's zebra are quite active during the first 90 days of pregnancy, and that the activity declines thereafter to stabilize at around 190 days of pregnancy. The gestational age of the pregnant mares in the present study (from which ovaries were sampled) exceeded 190 days for all but 1 female, in which it was 182 days. One would therefore expect a low-activity profile of the follicles of the pregnant mares in this study. 
Implantation has been reported to occur around 70 days after mating in Burchell's zebra (Smuts, 1975). Using the equation of Huggett \& Widdas (1951) for fetal growth we estimated that implantation occurs at $\sim 73$ days post coitum in Hartmann's zebras. This estimate is based on birth weight and gestation length published by Joubert (1974a, b). Joubert (1974a) used the method of Richter \& Gotze (1950) to estimate fetal growth (Fig. 1). The decline in fetal growth rate before birth suggested by him is at variance with that observed by others (see Huggett \& Widdas, 1951). The slope of our fetal growth curve (crown-rump length) differs from that of Joubert (1974a) (Fig. 2). He estimated the length of the foal at birth as an average of $120 \mathrm{~cm}(\mathrm{~N}=5)$, while the material in the present study $(\mathrm{N}=32$ ) suggests that length at birth would be $\sim 100 \mathrm{~cm}$.

In pregnant horse mares, plasma concentrations of progesterone rise to a high level in the beginning of pregnancy and reach a peak at the time of implantation. After implantation concentrations decline and, during the last month of pregnancy, increase again to about the same level as at the onset of pregnancy (Seren et al., 1981). Unfortunately, the present study contains only one specimen in relatively early pregnancy (95 days; implantation occurs at $\sim 73$ days, see above) and only one specimen close to parturition ( 345 days; parturition occurs at $\sim 362$ days, see above). In general, the progesterone concentrations in pregnant Hartmann's zebras were much lower than in the horse mare. No tendency for an increase in progesterone values towards the end of gestation, as in the horse mare, could be deduced from the present material.

The range of progesterone concentrations found in the fetal blood approached that found in non-pregnant mares. The presence of progesterone in the fetal blood may be explained by placental transfer. This is known to occur in sheep and humans (Heap, 1972). Progesterone is, however, rapidly metabolized in the fetus, and the concentrations of progestagens are thus effectively reduced.

The material at our disposal suggests that most matings occurred between November and April $(81 \%)$, with a peak in December. This correlates well with the daylight peak as well as with the onset of the rainy season. It is also in agreement with the foaling data given for this species by Joubert (1974b). On the other hand, another subspecies, the Cape mountain zebra, E. z. zebra, foals throughout the year at more southerly latitudes, although significantly more foals are born in summer (Penzhorn, 1985; Penzhorn \& Lloyd, 1987). Penzhorn (1985) also found that when the rains are late the conception date can be delayed in Cape Mountain zebras.

We thank the University of Pretoria and the Foundation for Research Development (Council for Scientific and Industrial Research) who provided financial support. The South West African Department of Agriculture and Nature Conservation provided logistical support and the project was carried out at their incentive.

\section{References}

Arthur, G.H. (1958) An analysis of the reproductive function of mares based on post mortem examination. Vet Rec. 34, 682-685.

Buys, M.E.L. (1978) Duration of daylight in South Africa. Technical Communication No 144. Department of Agricultural Technical Services, Republic of South Africa.

Ginther, O.J. (1979) Reproductive Biology of the Mare. Basic and Applied Aspects, 413pp. McNaughton and Gunn Inc., Ann Arbor.

Hammond, J. (1927) The Physiology of Reproduction in the Cow, 226pp. Cambridge University Press.

Heap, R.B. (1972) Role of hormones in pregnancy. In Reproduction in Mammals, vol. 3, pp. 73-105 Hormones in Reproduction. Eds C. R. Austin \& R. V. Short. Cambridge University Press.
Huggett, A.St.G. \& Widdas, W.F. (1951) The relationship between mammalian foetal weight and conception age. J. Physiol., Lond. 114, 306-317.

Joubert, E. (1974a) Size and growth as shown by pre and postnatal development of the Hartmann zebra Equus zebra hartmannae. Madoqua 1, 55-58.

Joubert, E. (1974b) Notes on the reproduction in Hartmann zebra Equus zebra hartmannae in South West Africa. Madoqua 1, 31-35.

King, J.M. (1965) A field guide to the reproduction of the Grant's zebra and Grevy's zebra. E. Afr. Wildl. J. 3, 99-117.

Kupfer, M. (1928) The sexual cycle of female domestic mammals. 13th and 14th Reports of the Director of Veterinary Education and Research. Government Printer, Pretoria. 
Mossman, H.W. \& Duke, K.L. (1973) Comparative Morphology of the Mammalian Ovary, 46lpp. University of Wisconsin Press, Wisconsin.

Penzhorn, B.L. (1985) Reproductive characteristics of a free-ranging population of Cape Mountain zebra (Equus zebra zebra). J. Reprod. Fert. 73, 51-57.

Penzhorn, B.L. \& Lloyd, P.H. (1987) Comparisons of reproductive parameters of two Cape mountain zebra (Equus zebra zebra) populations. J. Reprod. Fert., Suppl. 35, 661-663.

Richter, J. \& Gotze, R. (1950) Lehrbuch der Tiergeburtshilfe. H. Laupp Jr., Tübingen, Germany.

Seren, E., Tamanini, C., Gaiani, R. \& Bono, G. (1981) Concentrations of progesterone, $17 \beta$-hydroxyprogesterone and $20 \alpha$-dihydroprogesterone in the plasma of mares during pregnancy and at parturition. $J$. Reprod. Fert. 63, 443-448.
Smithers, R.H.N. (1983) The Mammals of the Southern African Subregion. University of Pretoria, Pretoria, Republic of South Africa.

Smuts, G.L. (1975) Pre- and postnatal growth phenomena of Burchell's zebra Equus burchelli antiquorum. Koedoe 18, 69-102.

Smuts, G.L. (1976) Reproduction in the zebra mare Equus burchelli antiquorum from the Kruger National Park. Koedoe 19, 89-132.

Van Aarde, R.J. (1985) Circulating progesterone and oestradiol-17ß concentrations in cyclic Cape porcupines, Hystrix africaeaustralis. J. Reprod. Fert. 75, 583-591. 